\title{
Subordinative Clause with Lemun Marker in Sasak Language
}

\author{
Ida Ayu Putu Aridawati ${ }^{1}$ Ida Bagus Rai Putra ${ }^{2}$ Ni Putu Parmini ${ }^{3}$ \\ ${ }^{1}$ Balai Bahasa Provinsi Bali, Jalan Trengguli 1 No. 34, Tembau, Denpasar \\ Phone (0361) 461714, Fax (0361) 463656 \\ ${ }^{2}$ Universitas Udayana \\ ${ }^{3}$ IKIP Saraswati Tabanan \\ *Corresponding author. Email: dayuarida1963@gmail.com
}

\begin{abstract}
The word lemun 'that' is one of the conjunction markers in subordinate clauses, which can connect lingual units to form larger lingual units (connecting main clauses and subordinate clauses). The problems discussed, namely sentence construction with main clauses predicated on N-D verbs, sentence construction with main clauses predicated on N-Dang verbs, sentence construction with main clauses predicated with $\mathrm{N}$-D-in verbs, and sentence construction with main clauses predicated on be- verbs. The purpose of this study is to obtain detailed descriptions of sentences constructed with main clauses predicated on N-D verbs, sentence construction with main clauses predicated on N-D-ang verbs, sentence construction with main clauses predicated on N-D-in verbs, and sentence construction with main clauses predicated on be- verbs. The theory used is structural linguistic theory. Data were collected using the method of observation (observation) and the method of interview (interview), supported by the technique of recording and translation. The distributional methods supported by substitution, turning, inserting, and expanding techniques are used in data analysis. Formal and informal methods supported by inductive and deductive techniques are used in presenting the results of data analysis. Based on the data analysis performed, it was concluded that the lemun conjunction connects the main clause and not the main clause. Determination of subordinate clauses in sentences can be observed by looking at the verbs that occupy the predicate function in the main clause. Lemun marker can form some sentence constructions, namely sentence construction with main clauses predicated by ND verbs, ND-ang verbs, ND-in verbs, and be- verb.
\end{abstract}

Keywords: subordinate clause, lemun marker, Sasak language.

\section{INTRODUCTION}

A clause is a grammatical unit that has a level above a phrase and below a sentence, in the form of a group of words that at least consists of a subject and a predicate, and has the potential to become a sentence. It is said to have the potential to become a sentence because even though it is not a sentence, in many respects a clause is no different from a sentence, except in the absence of final intonation or punctuation that characterizes the sentence [1]. A similar opinion was expressed by Sugono [2], that a clause is a grammatical unit in the form of a group of words, at least consisting of a subject and a predicate, and has the potential to become a sentence. Meanwhile, Sulaga et al. [3] suggest, of the two elements, the predicate element is more important than the subject element. Based on the main idea, it is clear that the behaviour of the word unit as an element of a clause has a certain function. The situation is different from the phrase because the element of the phrase cannot be permuted, while in the permutation clause it is one of the characteristics. Judging from the structure, the level of the clause is above the level of words, phrases, below the level of sentences. The clause as a grammatical level below the sentence level has the potential to form a sentence. Thus, a clause can form a complete sentence when the clause occupies a gatra in the sentence, such as a phrase. The main difference between a clause and a sentence lies in the layer of intonation [4]. 
The subordinating clause can be found in multilevel plural sentences. Thus, in a multilevel plural sentence, apart from a superior clause which is commonly known as the main clause, the main clause, or a matrix clause, there is also a subordinate clause or an embedding clause, or a subordinate clause. Subordinating clauses can be in the form of complementing clauses and controlling clauses. The difference between a complement clause and a controlling clause is in their function. Complementary clauses serve to add to the specification of the relationship between the meanings of the words or phrases that follow. Syntactically the presence of a restriction clause is optional, while the presence of a complement clause is mandatory. Complementary in this study includes the constituent phrases or clauses that follow the word which functions to complete the specification of the meaning relationship contained in the word itself. The complement includes sentence constituents commonly called objects, complements, and descriptions whose presence is complementary to the meaning of the sentence [5]. Many issues can be raised concerning clauses. However, this study only discussed the issue of the "Subordinate Clause with Lemun Marker in the Sasak language." This study is one of the efforts oriented towards the preparation of Sasak Grammar and is expected to improve the quality of use of the Sasak language among the speech community.

The problems studied were the construction of sentences with the main clause predicated as N-D verbs, $\mathrm{N}$-D-ang, N-D-in, and the verb be-. Thus, this study aims to obtain a detailed description of sentence construction with the main clauses predicated as N-D, $\mathrm{N}$-D-ang, N-D-in, and be- verbs

\section{THEORETICAL FRAMEWORK}

The theoretical framework of this study refers to the structural theory and is supported by the concept of clause analysis proposed by linguists. According to Ramlan [6], a clause is a grammatical unit that consists of a predicate, whether or not it is accompanied by $\mathrm{S}, \mathrm{O}$, complement, and adverb. The formula indicates that the predicate is the main condition, while other functions are likely to be omitted. The priority is the predicate, while the other functions occupy the second priority. The function of the subject cannot be ignored. At the beginning of a clause, the presence of a subject tends to be mandatory. However, the second or third clause is most likely omitted the subject. Likewise, objects cannot be excluded because, for clauses that are predicated as transitive verbs, the presence of an object is mandatory. A clause is a predicative syntactic unit. That is, in the unit or construction there is a predicate, if in that unit there is no predicate, then the unit is not a clause (Chaer [7]). According to Alwi [8], the clause is used to refer to a row of words that have at least a subject and a predicate, but do not yet have a certain intonation or punctuation. Tarigan [9] suggests that a clause is a group of words that only contains one predicate. Clauses as language units have three types of behaviour, namely (a) clauses as slot fillers in sentences. Thus, the clause can occupy the syntactic functions of $S$, $\mathrm{P}$, O, complement, and adverb; (b) the clause must consist of at least one predicate, and (c) the clause has a sentence-like style. The behaviour of the clause elements related to one another is framed by certain functions.

\section{RESEARCH METHOD}

The researcher collected the data using observation and interview methods. The observation method is direct observation of existing phenomena [10]. Therefore, the researcher immediately observed every element of the language spoken by the informant. The interview method is a way of collecting data through questions and answers with information as sources to obtain primary data. Questions and answers conducted in this study were face-to-face interactions with informants. In conducting the interview, digging, finding, and capturing information from the informants are highlighted utilizing communication. As a comparison and complement to the data obtained in the field, several efforts had been made to obtain secondary data through literature study. Literature study is a way of obtaining data by reading books, writings that have to do with research problems. This method was assisted by recording, note-taking, and translation techniques. Some of the words, phrases, sentences, conversations, and stories spoken by the informants were recorded orthographically, then translated into Indonesian. Moreover, the elicitation technique was also used because the researcher is a Balinese speaker as well. The elicitation technique is a way of collecting data by trying to remember and looking for itself. In this case, the researcher also acts as an informant.

The data collected were analyzed using the distributional method. The distributional method is a method whose determining tool is part of the language in question. In other words, auxiliary words in the framework of the distributional method are always part or element of the language of the object of research itself, such as words, phrases, and clauses. This method was assisted by changing technique, turning technique, inserting technique, and extending technique. Presentation of the results of data analysis was done using formal and informal methods. The formal method is a way of presenting rules with signs and symbols, such as brackets, asterisks, and diagrams. The informal method is a way of presenting the rules with the formulation of words (Sudaryanto [10]). The technique used was inductive and deductive techniques

\section{DISCUSSION}

\subsection{Subordinating Clauses with Lemun Marker}

The word lemun, 'that', is one of the conjunction markers in subordinating clauses. Lemun conjunction is a word that connects one lingual unit with another 
lingual unit to form a larger unit. The lemun conjunction, 'that', serves as a link between clauses. Take a look at the following example sentences:

(1) Budi ngelapor lemun diriqna ndeq tao mayah kepeng sekolah ujuq bulan ni.

'Budi reported that he could not pay the school fees for this month.'

Sentence (1) consists of two clauses, namely the main clause and the subordinate clause. The main clause, the first one, has a predicate in the form of an $\mathrm{N}$ $\mathrm{D}$ intransitive verb, namely ngelapor or reported. The subordinate clause as the complementary clause of the sentence is located after the predicate which functions as a complement. The core and subordinate clauses are connected by the conjunction lemun (that). To prove that sentence (1) has an intransitive verb predicate in the main clause, that requires a complement as a complement, the sentence cannot be converted into a passive construction, as in the example sentence (1a). Furthermore, it can be proven by moving the location of the subordinate clause before the main clause such as sentence (1b).

(1a) *Lemun diriqna ndeq tao mayah kepeng sekolah ujuq bulan ni, telapor isiq Budi.

'That he couldn't pay his school fees for this month, was reported by Budi.'

(1b) *Lemun diriqna ndeq tao mayah kepeng sekolah ujuq bulan ni, Budi ngelapor.

'That he couldn't pay his school fees for this month, Budi reported'.

Sentences (1a) and (1b) are not grammatical and unacceptable. This proves that in sentence (1) the subordinate clause is a complementary clause that occupies a complementary function. The type of relationship stated by lemun 'that' is a content relationship because the subordinate clause is the content of the main clause

\subsection{Sentence Construction with N-D Verb Predicated Main Clauses}

The predicate function in the main clause in the form of N-D intransitive verbs can be used to determine the complementing clause.

(1) Rafi'ah mparan lemun Aguslah saq tepiliq jari calon direktur laeq perusahaan ni.

'Rafi'ah thought that it was Agus who was chosen to be a candidate for director of this company'.

(2) Nia ngeluh lemun keluargena teongkatang sebage keluarga pemberontak leq desa ni.

'She complained that her family was said to be a rebel family in this village'.
(3) Siti nganggep lemun Wahyu bedue jiwa saq lenge.

'Siti thinks that Wahyu has a rude personality.

Sentences $(1-3)$ consist of two clauses, namely the main clause and the subordinate clause. The main clause in the sentence $(1-3)$ is like Rafi'ah mparan 'Rafi'ah thought' (1), nia ngeluh 'she complained' (2), Siti nganggep 'Siti thinks' (3). The subordinate clause in the sentences (1 - 3), namely Aguslah saq terpilih jari calon direktur laeq perusahan $n i$ 'Agus who was chosen to be a candidate for director of this company' (1), keluargena teongkatang sebage keluarga pemberontak leq desa $n i$ 'her family was said to be a rebel family in this village' (2), and Wahyu badue jiwa saq lenge 'Wahyu has a rude personality' (3). The main clause has a predicate in the form of N-D intransitive active verbs, namely mparan 'thought' (1), ngeluh 'complained' (2), and nganggep 'thinks' (3). The subordinate clause as a complementary clause is located after the predicate $(\mathrm{N}$ $\mathrm{D}$ intransitive verb) which functions as a complement. The two clauses of the sentences $(1-3)$ are each connected by a marker in the form of the conjunction lemun 'that'. To prove that the sentence $(1-3)$ has an intransitive verb predicate in the main clause that requires a complement, the claim cannot be converted into a passive construction, as in the following sentence $(1 a-3 a)$

(1a) *Lemun Aguslah saq terpiliq jari calon direktur laeq perusahaan ni, teparan isiq Rafi'ah.

'That it was Agus who was chosen to be a candidate for director in this company, was thought by Rafi'ah'.

(2a) *Lemun keluargena teongkatang sebage keluarga pemberontak leq desa ni, tekeluh isiq nia.

'That her family is said to be a rebel family in this village, complained by her'.

(3a) *Lemun Wahyu bedue jiwa saq lenge, teanggep isiq Siti.

'That Wahyu has a rough personality, is considered by Siti'.

Other proofs can be done by moving the subordinate clause such as the following sentences.

(1b) *Lemun Aguslah saq tepiliq jari calon direktur laeq perusahaan ni, Rafi'ah mparan.

'That Agus was chosen as a candidate for director in this company, Rafi'ah thought'.

(2b) *Lemun keluargena teongkatang sebage keluarga pemberontak leq desa ni, nia ngeluh .

'That her family is said to be a rebel family in this village, she complained'.

(3b) *Lemun Wahyu bedue jiwa saq lenge, Siti nganggep. 
'That Wahyu has a rude personality, Siti thinks'.

Sentences (1a - 3a) and $(1 b-3 b)$ are not grammatical and unacceptable. This proves that in the sentence $(1-3)$, the subordinate clause is a subordinate clause that occupies a complementary function. The type of relationship expressed by the lemun 'that' conjunction is the content of the main clause. In other words, the subordinate clause states what is suspected, what is thought, what is complained about, what is considered in the main clause. The conjunction of lemun is closely related to the predicate of the core clause which is an N-D intransitive verb.

\subsection{Sentence Construction with Main Clause with Predicated Verb $N$-D-ang}

Determination of subordinate clauses in sentences can be observed from the verbs that occupy the predicate function in the core clause. If the function of the predicate in the main clause is a transitive active verb N-D-ang, the function of the subordinate clause can be determined. Take a look at the sentences below.

(1) Amaq njelasang lemun bahan-bahan bangunan no eaq tekeduang ujuq kerisaq pawon dait kamar mandiq.

'Father explained that the building materials would be used to repair the kitchen and bathroom'.

(2) Inaq mbaqdinang lemun kakaq uah lampaq oneq kelemaq.

'Mother told me that my sister had left this morning'.

(3) Marwah mbeberaqang lemun Ani teterimaq leq Fakultas Hukum Universitas Mataram.

'Marwah reported that Ani was accepted at the Faculty of Law, Universitas Mataram'.

Sentence $(1-3)$ consists of two clauses, namely the first clause is the main clause and the second clause is a subordinate clause. The main clause has a predicate in the form of an N-D-ang transitive active verb, such as njelasang 'explained' (1), mbaqdinang 'told' (2), mbebaraqang 'reported' (3). The main clause presents a subordinate clause. In other words, the main clause is followed by a subordinate clause. The subordinate clause in sentences $(1-3)$ serves as an object since it is located after the predicate of the transitive verb N-Dang of the main clause. The main and subordinate clauses are connected by the conjunction lemun 'that'. To prove that sentence $(1-3)$ has a transitive verb predicate in the main clause and requires completion as an object, the sentence is converted into a passive construction, as in the following example sentence. To prove that sentence $(1-3)$ has a transitive verb predicate in the main clause and requires completion as an object, the sentence is converted into a passive construction, as in the following example sentence. (1a) Lemun bahan-bahan bangunan no eaq tekeduang ujuq kerisaq pawon dait kamar mandiq, tejelasang isiq amaq.

'That the building materials will be used to repair the kitchen and bathroom, was explained by father.'

(2a) Lemun kakaq uah lampaq oneq kelemaq, tebaqdinang isiq inaq.

'That brother left this morning, was informed by mother.'

(3a) Lemun ani teterimaq leq Fakultas Hukum Universitas Mataram, tebebaraqang isiq Marwah.

'That Ani was accepted at the Faculty of Law, Universitas Mataram, was reported by Marwah'.

Another proof can be done by moving the subordinate clause before the main clause. Look at the sentences $(1 b-3 b)$ below.

(1b) *Lemun bahan-bahan bangunan no eaq tekeduang ujuq kerisaq pawon dait kamar mandiq, amaq njelasang.

'That the building materials will be used to repair the kitchen and bathroom, father explained'.

(2b) *Lemun kakaq uah lampaq oneq kelemaq, inaq mbaqdinang.

'That brother left this morning, mother told me.'

(3b) *Lemun Ani teterimaq leq Fakultas Hukum Universitas Mataram, Marwam mbebaraqang.

'That Ani was accepted at the Faculty of Law, Universitas Mataram, Marwah reported'.

Sentence $(1 \mathrm{a}-3 \mathrm{a})$ is grammatical and acceptable, while sentence $(1 b-3 b)$ is not grammatical. This proves that in the sentence $(1-3)$ the subordinate clause is a subordinate clause that occupies the function of the object. The type of relationship stated by the lemun 'that' conjunction is the relationship of the content of the main clause, namely what is explained, what is said, what is told, and what is reported. The conjunction of lemun is closely related to the predicate of the main clause of the verb N-D-ang.

\subsection{Conjunction Sentences with Main Clause with Predicated Verbs $N$-D-in}

The determination of the subordinate clause in the sentence can be observed by looking at the verb that occupies the predicate function in the main clause. Look at the example sentences below.

(1) Nana mahamin geti lemun pegawean semamena mulen butuhang dedikasi tinggi.

'Nana understands well that her husband's job does require high dedication'. 
(2) Pimpinan perusahaan sino nyanggupin lemun selapuq pegawai eaq teteeqang gajina uling bulan muriq.

'The head of the company agrees that all employees would have their salaries increased starting next month'.

Sentences $(1-2)$ consist of two clauses, namely the main clause and the subordinate clause. The main clause has a predicate in the form of an N-D-in transitive active verb, such as mahamin 'understands' (1) and nyanggupin 'agrees' (2). The main clause is followed by a main clause as a subordinate clause. The subordinate clauses $(1-2)$ function as an object because it is located after the transitive verb predicate N-D-in the main clause. The main and subordinate clauses are connected by the conjunction lemun 'that'. Transitive sentences (1 -2) can be made into a passive construction, such as the following sentence $(1 a-2 a)$.

(1a) Lemun pegawean semamena mulen butuhang dedikasi tinggi, tepahamin geti isiq Nana.

'That her husband's job does require high dedication, Nana understands well'.

(2a) Lemun selapuq pegawai eaq teteeqang gajina uling bulan muriq, tesanggupin isiq pimpinan perusahaan sino.

'That all employees will have their salaries increased starting next month, the company leadership agrees to do'.

Besides being able to be changed into passive sentences, sentences $(1-2)$ can also be moved, such as the subordinate clause precedes the main clause, as in the following sentences $(1 b-2 b)$.

(1b) *Lemun pegawean semamena mulen butuhang dedikasi tinggi, Nana mahamin geti.

'That her husband's job does require high dedication, Nana understands well'.

(2b) *Lemun selapuq pegawai eaq teteeqang gajina uling bulan muriq, pimpinan perusahaan sino nyanggupin.

'That all employees will have their salaries increased starting next month, the company leader agrees'.

Sentences $(1 \mathrm{a}-2 \mathrm{a})$ are grammatical and acceptable, while sentences $(1 b-2 b)$ are not grammatical. This proves that the sentences $(1-2)$ have a transitive verb predicate in the main clause and requires a complement that occupies the object function. The type of relationship expressed by the lemun 'that' conjunction is the relationship of the content of the main clause. The subordinate clause states what is understood and what is said in the main clause. The lemun 'that' conjunction is after the main clause predicate, indicating that the conjunction is closely related to the main clause predicate in the form of N-D-in transitive verbs.

\subsection{Conjunction Construction with Main Clause with Predicated Verb be-}

The predicate function of the main clause in the form of a transitive active verb be- can be used to determine the subordinate clause. Look at the example sentences below.

(1) Marwah bepikir lemun kanaq-kanaq sino pasti kuang mauq kasih sayang leq balenna.

'Marwah thinks that the children must be lacking in affection at home.

(2) Kakaqna berongkat lemun ariq-ariqna tetep nurutin ongkat-ongkatna.

'Their older sibling said that his brothers always followed his word'.

Sentences $(1-2)$ consist of two clauses, namely the first clause in the form of the main clause of Marwah bepikir 'Marwah thinks' (1) and the second clause in the form of a subordinate clause kanaq-kanaq sino pasti kuang mauq kasih sayang leq balenna 'the children must be lacking in affection at home' (2). The main clause has a predicate in the form of an intransitive verb be-, namely bepikir 'thinks' (1) and berongkat 'said' (2). The subordinate clauses of the sentences $(1-2)$ occupy a complementary function because it is located after the predicate of the intransitive active verb in the main clause. The main clauses and subordinate clauses are connected by the lemun 'that' conjunction. To prove that the subordinate clause functions as a complement, the sentence $(1-2)$ cannot be changed into a passive sentence, as in the following sentences $(1 \mathrm{a}-2 \mathrm{a})$

(1a) *Lemun kanaq-kanaq sino pasti kuang mauq kasih sayang leq balenna, tepikir isiq Marwah.

'That the children must be lacking in affection at home, thought Marwah.'

(2a) *Lemun ariq-ariqna tetep nurutin ongkatongkatna, teongkat isiq kakaqna.

'That his brothers always followed his word, said their older sibling'.

Another proof can be done by moving the location of the subordinate clause before the main clause, as in the following sentence.

(1b) *Lemun kanaq-kanaq sino pasti kuang mauq kasih sayang leq balenna, aku bepikir.

'That the children must be lacking in affection at home, Marwah thinks.'

(2b) *Lemun ariq-ariqna tetep nurutin ongkatongkatna, kakaqna berongkat. 
'That his brothers always followed his word, their older sibling said'.

Sentences $(1 a-2 a)$ and $(1 b-2 b)$ are not grammatical and unacceptable. This proves that the sentence $(1-2)$ has an intransitive verb predicate in the main clause and requires a complement that occupies a complementary function. The type of relationship stated by the lemun 'that' conjunction in the sentences $(1-2)$ is the relationship between the content of the main clause. The subordinate clause states what is thought and what is said in the main clause. The lemun 'that' conjunction is closely related to the predicate of the main clause in the form of the intransitive verb be-

\section{CONCLUSION}

Based on the discussion above, it can be concluded that the word lemun 'that' is one of the markers of conjunctions in subordinating clauses. Lemun conjunction is a word that connects lingual units to form a larger lingual unit (connecting main clause and subordinate clause). The determination of the subordinate clause in the sentence can be observed by looking at the verb that occupies the predicate function in the main clause. The lemun marker can form several sentence constructions, namely sentence construction with the main clause with an ND verb predicate, a sentence construction with an ND-ang verb predicated main clause, a sentence construction with an ND-in verb predicate as the main clause, and sentence construction with a $b e$ - verb predicate clause. Transitive verbs function as the predicate of the main clause in complex sentences, the subordinate clause completes the main clause. The subordinate clause which is located after the transitive verb in the main clause occupies the function of the object. As an object, this constituent can occupy the function of the subject and can be changed from active sentence construction to passive sentence construction. Intransitive verbs function as the predicate of the main clause in complex sentences, the subordinate clause completes the main clause that is located after the verb (predicate) and the main clause occupies a complementary function. As a complement, the main clause cannot occupy the function of the subject and cannot be changed from active sentence construction to passive sentence construction.

\section{ACKNOWLEDGMENTS}

The title "ACKNOWLEDGMENTS" should be in all caps and should be placed above the references. The references should be consistent within the article and follow the same style. List all the references with full details.

\section{REFERENCES}

[1] Kridalaksana, H. (2008). Linguistics Dictionary. Jakarta: Gramedia.
[2] Sugono, D., et al. (2008). Great Dictionary of the Indonesian Language. Jakarta: PT Gramedia Pustaka Utama.

[3] Sulaga, I. N., et al. (1992). Balinese Grammar Denpasar: Indonesian and Balinese Language and Literature Research Project, Ministry of Education and Culture.

[4] Arifin, E., Zaenal, \& Junaiyah. (2008). Indonesian Syntax. Jakarta: PT Grasindo.

[5] Lapoliwa, H. (1990). Complementary Clauses in Indonesian. Jakarta: Kanisius.

[6] Ramlan, M. (2005). Syntax. Yogyakarta: CV Karyono.

[7] Chaer, A. (2009). Introduction to Indonesian Semantics. Jakarta: Rineka Cipta.

[8] Alwi, H., et al. (2003). Indonesian Standard Grammar. Jakarta: Balai Pustaka.

[9] Tarigan, H.G. (2009). Syntax Principles. Bandung: Angkasa.

[10] Sudaryanto. (1993). Methods and Various Language Analysis Techniques. Yogyakarta : Duta Wacana University Press. 